\title{
Erratum to: Determinants of acute malnutrition among children aged 6-59 months in Public Hospitals, Oromia region, West Ethiopia: a case-control study
}

Amsalu Bokore Ayana ${ }^{1 *}$, Tsedeke Wolde Hailemariam ${ }^{2}$ and Alemu Sufa Melka ${ }^{3}$

Erratum to: BMC Nutrition20151:34 DOI: 10.1186/ s40795-015-0031-9

Following publication of the original version [1] of the article of the BMC Nutrition 2015, it was bought to our attention that an authors name was incorrectly published. The authors name should be presented as "Alemu Sufa Melka" and not "Alemu Sufa Melke".

\begin{abstract}
Author details
'Department of Public Health, College of Medical and Health Sciences, Wollega University, Nekemte, Ethiopia. ${ }^{2}$ Nutrition Unit, Population \& Family Health Department, College of Public Health and Medical Sciences, Jimma University, Jimma, Ethiopia. ${ }^{3}$ Reproductive Health Unit, Department of Public Health, College of Medical and Health Sciences, Wollega University, Nekemte, Ethiopia.
\end{abstract}

Received: 29 December 2015 Accepted: 5 January 2016

Published online: 11 January 2016

\section{Reference}

1. Ayana et al. Determinants of acute malnutrition among children aged 6-59 months in Public Hospitals, Oromia region, West Ethiopia: a case-control study. BMC Nutrition. 2015;1:34.

\footnotetext{
* Correspondence: bokore.amsalu@yahoo.com

Submit your next manuscript to BioMed Central and we will help you at every step:

- We accept pre-submission inquiries

- Our selector tool helps you to find the most relevant journal

- We provide round the clock customer support

- Convenient online submission

- Thorough peer review

- Inclusion in PubMed and all major indexing services

- Maximum visibility for your research

Submit your manuscript at www.biomedcentral.com/submit
() Biomed Central 